Kuchma Igor L., Gozhenko Anatoliy I., Bilas Volodymyra R., Huchko Bohdan Y., Ponomarenko Ruslan B., Nahurna Yaryna V., Zukow Walery, Popovych Igor L. Relationships between parameters of nitrogenous metabolites and HRV in humans exposed to the factors of the accident at the Chornobyl Nuclear Power Plant. Journal of Education, Health and Sport. 2021;11(1):253-268. eISSN 2391-8306. DOI http://dx.doi.org/10.12775/JEHS.2021.11.01.025

https://apcz.umk.pl/czasopisma/index.php/JEHS/article/view/JEHS.2021.11.01.025

https://zenodo.org/record/4667900

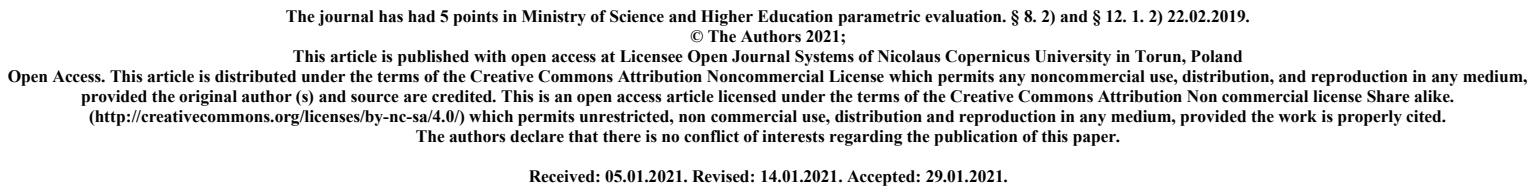

Received: 05.01.2021. Revised: 14.01.2021. Accepted: 29.01.2021.

\title{
RELATIONSHIPS BETWEEN PARAMETERS OF NITROGENOUS METABOLITES AND HRV IN HUMANS EXPOSED TO THE FACTORS OF THE ACCIDENT AT THE CHORNOBYL NUCLEAR POWER PLANT
}

\author{
Igor L. Kuchma ${ }^{1}$, Anatoliy I. Gozhenko ${ }^{1}$, Volodymyra R. Bilas ${ }^{5}$, Bohdan Y. Huchko, \\ Ruslan B. Ponomarenko ${ }^{2}$, Yaryna V. Nahurna ${ }^{3}$, Walery Zukow ${ }^{4}$, Igor L. Popovych ${ }^{1,5}$ \\ ${ }^{1}$ Ukrainian Scientific Research Institute for Medicine of Transport, Odesa, Ukraine \\ igorkuchma@ukr.net; prof.gozhenko@gmail.com; \\ ${ }^{2}$ Communal Hospital, Truskavets', Ukraine \\ ${ }^{3}$ Danylo Halyts'kyǐ National Medical University, L'viv, Ukraine nyv86@ukr.net \\ ${ }^{4}$ Nicolaus Copernicus University, Torun, Poland w.zukow@wp.pl \\ ${ }^{5}$ Bohomolets' OO Institute of Physiology of National Academy of Sciences, Kyïv, \\ Ukraine i.popovych@biph.kiev.ua
}

\begin{abstract}
Background. We have previously shown that nitrogenous metabolites have immunomodulatory effects, both suppressor and enhancing, both in healthy rats and in humans exposed to pathogenic influences. The immunomodulatory effect of bilirubin is probably mediated through aryl hydrocarbon receptors, and uric acid through TL- and adenosine receptors of immune cells. The question of mediators of the immunomodulatory action of urea and creatinine remains open. We hypothesized the mediating role of mediators of the autonomic nervous system and adaptation hormones. The aim of this study is to analyze the relationships between the parameters of nitrogenous metabolites, on the one hand, and HRV markers of the parameters of the autonomic nervous system - on the other hand. Material and methods. The object of observation in 1997 were 19 men and 3 women who were exposed to pathogenic factors of the accident at the Chornobyl nuclear power plant during the liquidation of its consequences in 1986-87. The survey was conducted twice - on admission and after two weeks of rehabilitation at the Truskavets' Spa. The plasma and urinary concentration of the nitrogenous metabolites were determined. The state of the autonomic nervous system (ANS) was judged by the HRV parameters recorded before and after submaximal bicycle ergometric loading. Results. Both negative and positive metabolicANS correlations were revealed. Calculation of multiple correlation coefficients between individual metabolite parameters and constellations of HRV parameters revealed the
\end{abstract}


maximum vegetotropic effect of Urea plasma $(\mathrm{R}=0,700)$ and Uric acid urine $(\mathrm{R}=0,623)$. This is followed by Urea urine $(\mathrm{R}=0,531)$ and Creatinine plasma $(\mathrm{R}=0,457)$. No significant correlations were found for Creatinine urine, Uric acid plasma and Bilirubinemia. The canonical correlation between the constellation of nitrogenous metabolites, on the one hand, and the HRV markers of ANS, on the other hand, was strong: $\mathrm{R}=0,747 ; \chi_{(28)}^{2}=63 ; \mathrm{p}<10^{-3}$. Conclusion. Previously identified immunomodulatory effects of urea and creatinine are realized, possibly through cholinergic and adrenergic mechanisms.

Key words: urea, uric acid, creatinine, bilirubin, HRV, relationships, humans.

\section{INTRODUCTION}

We have previously shown that nitrogenous metabolites have immunomodulatory effects, both suppressor and enhancing, both in rats [10,11,29] and in humans [12,13,19,33]. The immunomodulatory effect of bilirubin is probably mediated through aryl hydrocarbon receptors [2,6,26,30], and uric acid through TL- and Adenosine receptors [1,7,15,16,22,23,35] of immune cells. The question of mediators of the immunomodulatory action of urea and creatinine remains open. We hypothesized the mediating role of mediators of the autonomic nervous system and adaptation hormones [19] in line with the concepts of neuroendocrineimmune complex [14,27] and functional-metabolic continuum [9]. The aim of this study is to analyze the relationships between the parameters of nitrogenous metabolites, on the one hand, and HRV markers of the parameters of the autonomic nervous system - on the other hand.

\section{MATERIAL AND METHODS}

The database of the Truskavetsian Scientific School of Balneology [18,28] was used for the research. The object of observation in 1997 were 19 men $(26 \div 61 \mathrm{y})$ and 3 women $(38,40$ and $47 \mathrm{y}$ ) with urolithiasis and chronic pyelonephritis who were exposed to pathogenic factors of the accident at the Chornobyl nuclear power plant during the liquidation of its consequences in 1986-87. According to the documents, the total effective radiation dose was $10 \div 25$ cGy, which is most typical for this contingent [28,31]. The survey was conducted twice: on admission and after two weeks of rehabilitation at the Truskavets' Spa.

The plasma level of the nitrogenous metabolites determined: creatinine (by Jaffe's color reaction by Popper's method), urea (urease method by reaction with phenolhypochlorite), uric acid (uricase method) and bilirubin (by diazoreaction using the Jedrashik-Kleghorn-Grof method). The same metabolites, with the exception of bilirubin, were also determined in the morning urine. The analyzes were carried out according to the instructions described in the manual [8]. The analyzers "Pointe-180" ("Scientific", USA) and "Reflotron" (Boehringer Mannheim, BRD) were used with appropriate sets.

State of autonomous nervous system was assessed by the method of HRV using the "Cardio" device (Kyiv). The classical parameters of Baevskiy were analyzed: Mode (Mo), Amplitude of the Mode (AMo) and variational swing (MxDMn) as markers of the humoral channel of regulation, sympathetic and vagal tones respectively $[3,4]$.

A feature of the design was the registration of HRV at rest (basal conditions, B) and immediately after the second bicycle ergometric load (L), which allowed the assessment of autonomic reactivity as $\mathrm{L} / \mathrm{B}$ ratio. 
A bicycle ergometer "Tunturi" (Finland) is used. The power of the first load was 0,5 $\mathrm{W} / \mathrm{kg}$ at a pedaling frequency of $60-75 \mathrm{rpm}$. The power of the second load (after $3 \mathrm{~min}$ ), according to the recommendations for a gentle version of the PWC test, taking into account the age of the subjects [5], was selected so that the HR at the end of the load was close to that calculated by the formula: $\mathrm{HR}=(220-$ Age $) \bullet 0,87$.

Results processed by using the software package "Statistica 20 ".

\section{RESULTS AND DISCUSSION}

In presenting the results, we will follow the algorithm used in previous studies [19].

Screening of linear correlation coefficients between parameters of nitrogenous metabolites, on the one hand, and the recorded HRV parameters, on the other hand, revealed the following (Table 1).

As you can see, the level of Urea in plasma is negatively correlated with Mode, which is considered a marker, especially of circulating catecholamines, as well as other positive chronotropic factors (glucocorticoids, thyroid hormones, glucagon, etc.). It is noteworthy that the correlation coefficients are almost the same both in basal conditions (Fig. 1) and after muscle load (Fig. 2), which, of course, reduces Mode (increases HR).

In contrast, plasma urea correlates significantly with the marker of vagal tone only after exercise (Fig. 4), whereas in basal conditions there is no connection (Fig. 3). It should be noted that under basal conditions, normal vagus tone $(0,15 \div 0,30 \mathrm{sec})$ [4] occurred only in 6 cases out of 44 , while in $86 \%$ it was reduced, and after exercise vagus tone in $32 \%$ was normal, and another $23 \%$ - elevated.

On the other hand, the normal level of sympathetic tone $(30 \div 50 \%)$ [4] in basal conditions occurred only in $16 \%$ of cases, and in $82 \%$ was elevated (Fig. 5). Exercise reduced the proportion of sympathicotonia to $45,5 \%$, reciprocally increasing the proportion of vagotonia from $2 \%$ to $34 \%$ (Fig. 6). This indicates a paradoxical vagotonic response to the muscular load of this group of patients. Obviously, this is a manifestation of post-radiation encephalopathy $[18,28,31]$.

Baevskyi's Stress index, which also takes into account Mode [3], is considered to be more informative for assessing the state of heart rhythm regulation systems. Eutonia is characterized by a range of $51 \div 199$ units (or $\operatorname{lnSI} 3,93 \div 5,29$ ), a range of $200 \div 500$ units indicates sympathicotonia, and more than 500 units - hypersympathicotonia [3,21]. According to this scale, euthonia is found in only $16 \%$ of cases, while sympathicotonia - in $34 \%$, and hypersympathicotonia - in $48 \%$, in the only case of vagotonia.

Naturally, the level of plasma urea correlates with sympathetic tone positively, but again only after exercise (Fig. 6), whereas in basal conditions the correlation is insignificant (Fig. $5)$, as well as with the tone of the vagus. 
Table 1. Matrix of correlations between nitrogenous metabolites and HRV parameters

\begin{tabular}{|l|c|c|c|c|c|c|c|}
\hline \multirow{2}{*}{ Variable } & \multicolumn{7}{l}{ Correlations } \\
\cline { 2 - 8 } & Urea U & UA U & Cr U & Urea P & Cr P & UA P & Bilir P \\
\hline Mode Basal & $-0,01$ & $-0,04$ & 0,09 & $-0,66$ & $-0,43$ & $-0,09$ & $-0,07$ \\
\hline AMo Basal & $-0,35$ & $-0,32$ & $-0,08$ & $-0,27$ & $-0,16$ & $-0,10$ & 0,12 \\
\hline MxDMn Basal & 0,51 & 0,51 & $-0,08$ & $-0,13$ & $-0,11$ & 0,02 & $-0,11$ \\
\hline In SI Basal & $-0,48$ & $-0,43$ & 0,03 & 0,14 & 0,10 & $-0,03$ & 0,12 \\
\hline Mode Loading & $-0,08$ & $-0,09$ & 0,13 & $-0,63$ & $-0,42$ & $-0,10$ & $-0,13$ \\
\hline AMo Loading & $-0,04$ & 0,02 & 0,11 & 0,60 & 0,39 & 0,07 & $-0,19$ \\
\hline MxDMn Loading & $-0,06$ & $-0,03$ & 0,07 & $-0,65$ & $-0,43$ & $-0,12$ & $-0,08$ \\
\hline In SI Loading & 0,03 & 0,02 & $-0,04$ & 0,65 & 0,42 & 0,11 & 0,03 \\
\hline In (SIL/SIB) & 0,29 & 0,25 & $-0,05$ & 0,48 & 0,31 & 0,11 & $-0,04$ \\
\hline AMoL/AMoB & 0,24 & 0,14 & 0,10 & 0,45 & 0,24 & 0,19 & $-0,23$ \\
\hline (MxDMnL)/(MxDMnB) & $-0,31$ & $-0,33$ & 0,04 & $-0,29$ & $-0,27$ & $-0,05$ & 0,06 \\
\hline
\end{tabular}

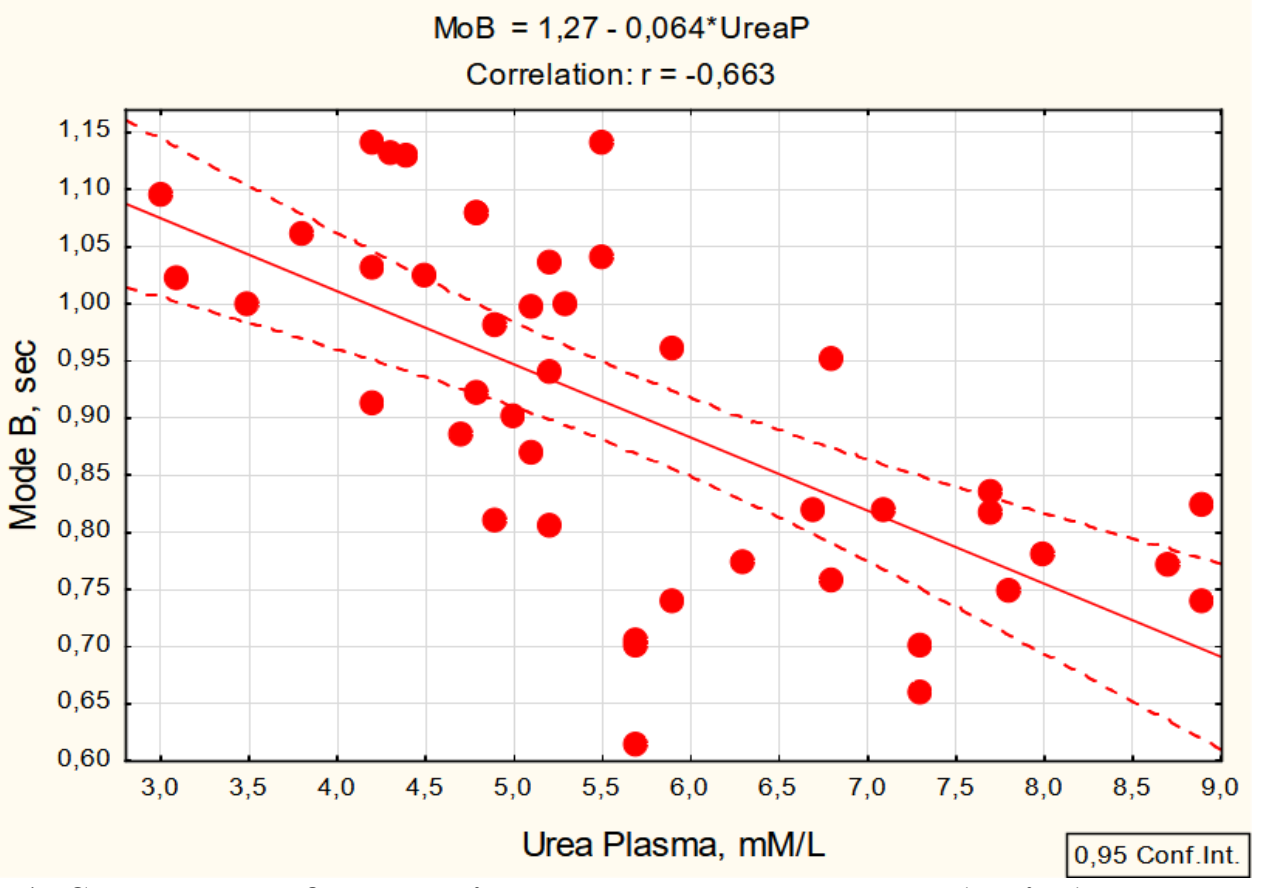

Fig. 1. Scatterplot of correlation between Urea Plasma (X-line) and Mode HRV basal (Y-line) 


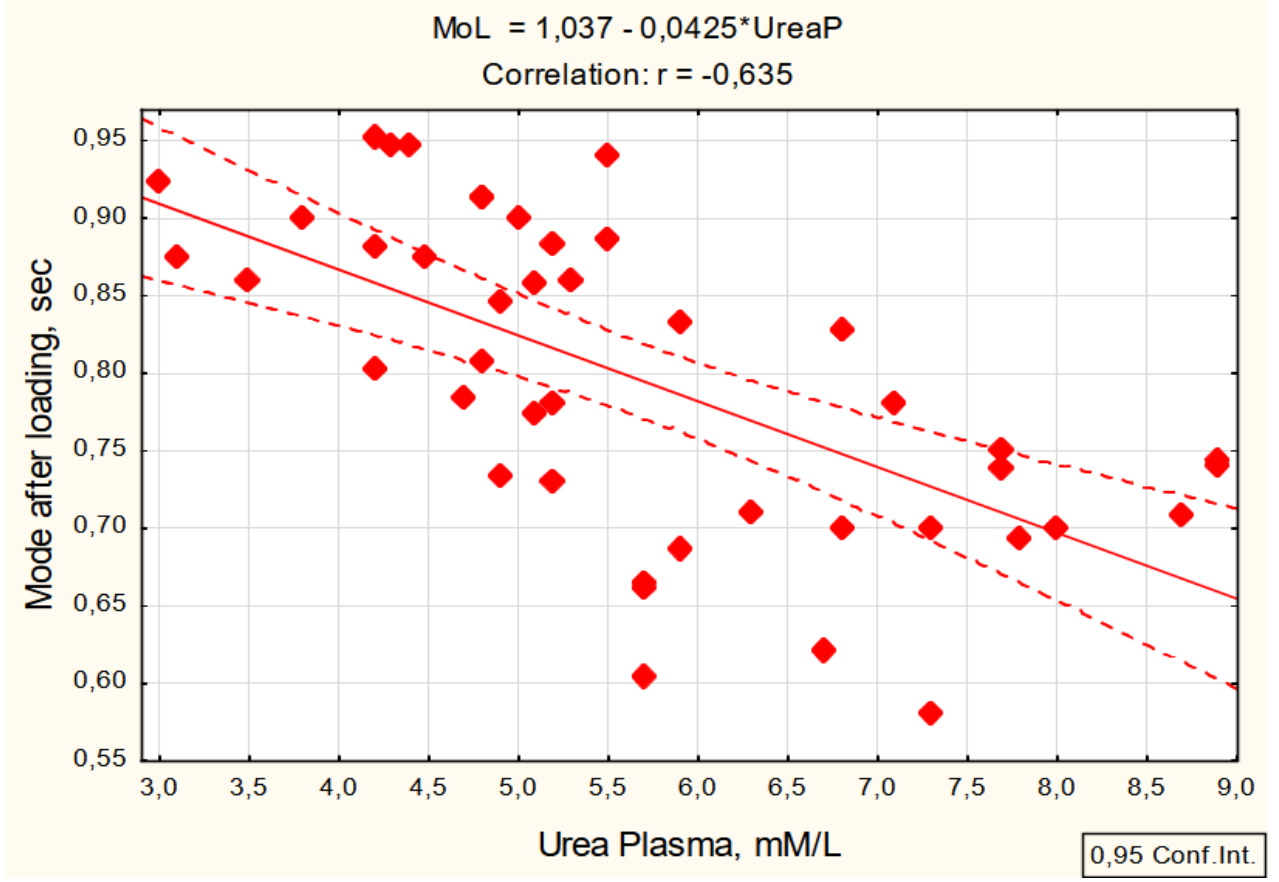

Fig. 2. Scatterplot of correlation between Urea Plasma (X-line) and Mode HRV after loading (Y-line)

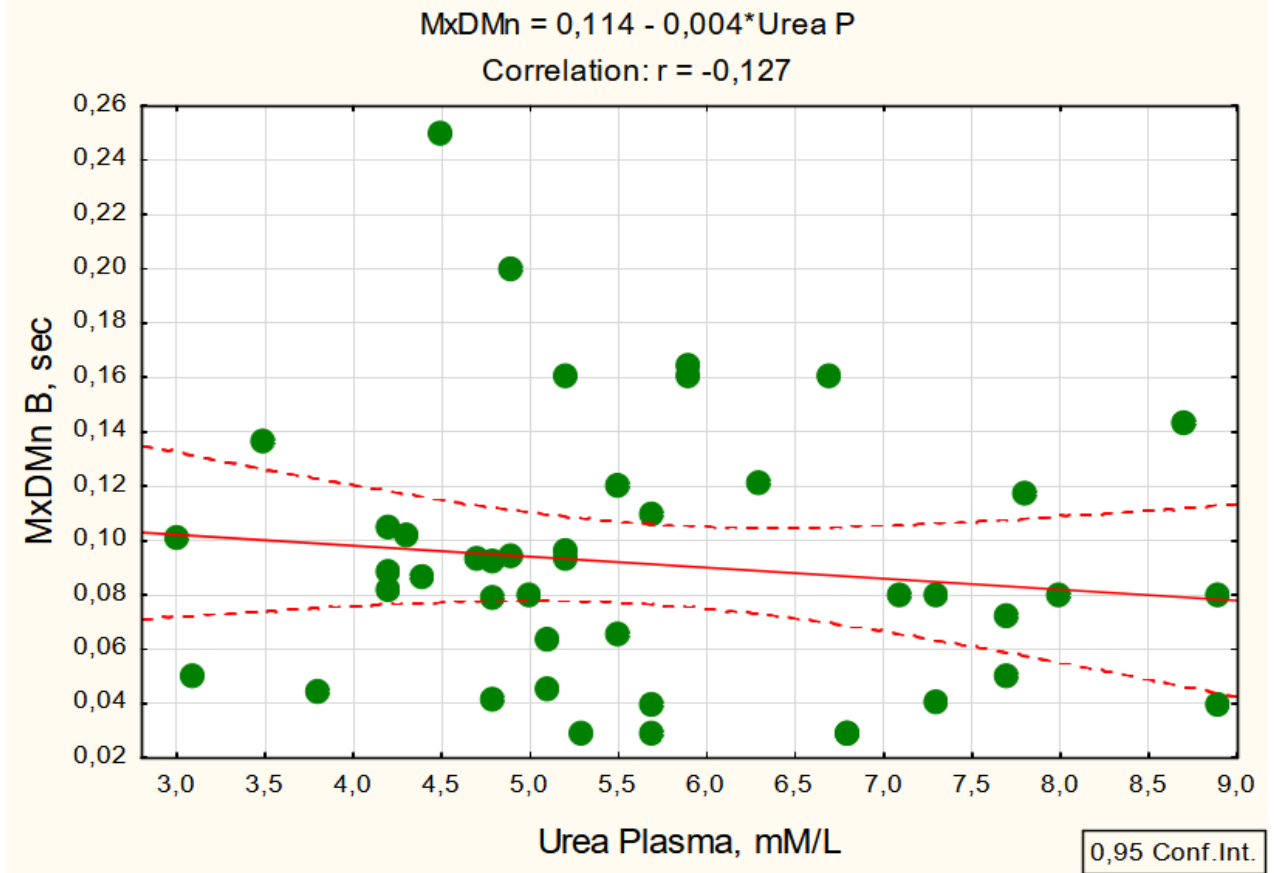

Fig. 3. Scatterplot of correlation between Urea Plasma (X-line) and MxDMn HRV basal (Y-line) 


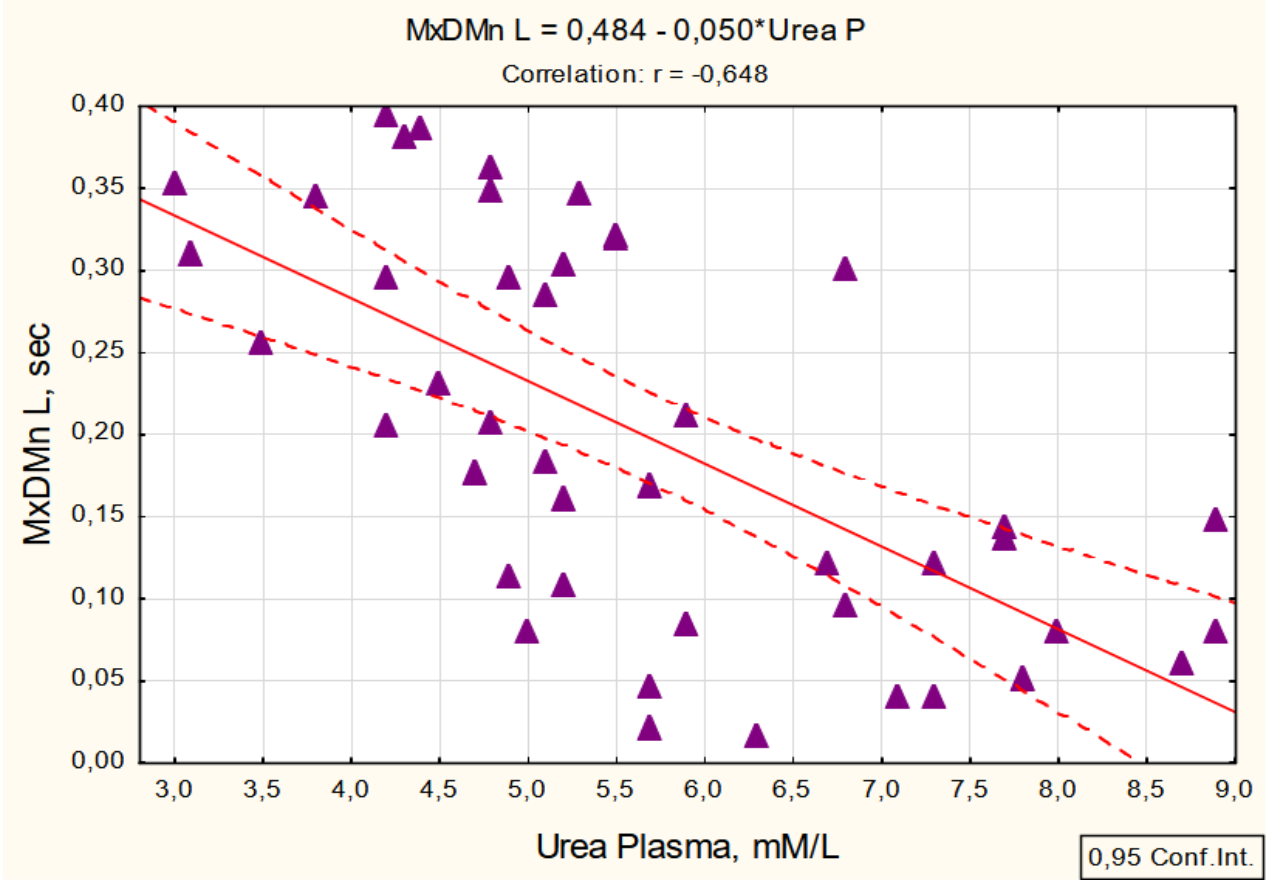

Fig. 4. Scatterplot of correlation between Urea Plasma (X-line) and MxDMn HRV after loading (Y-line)

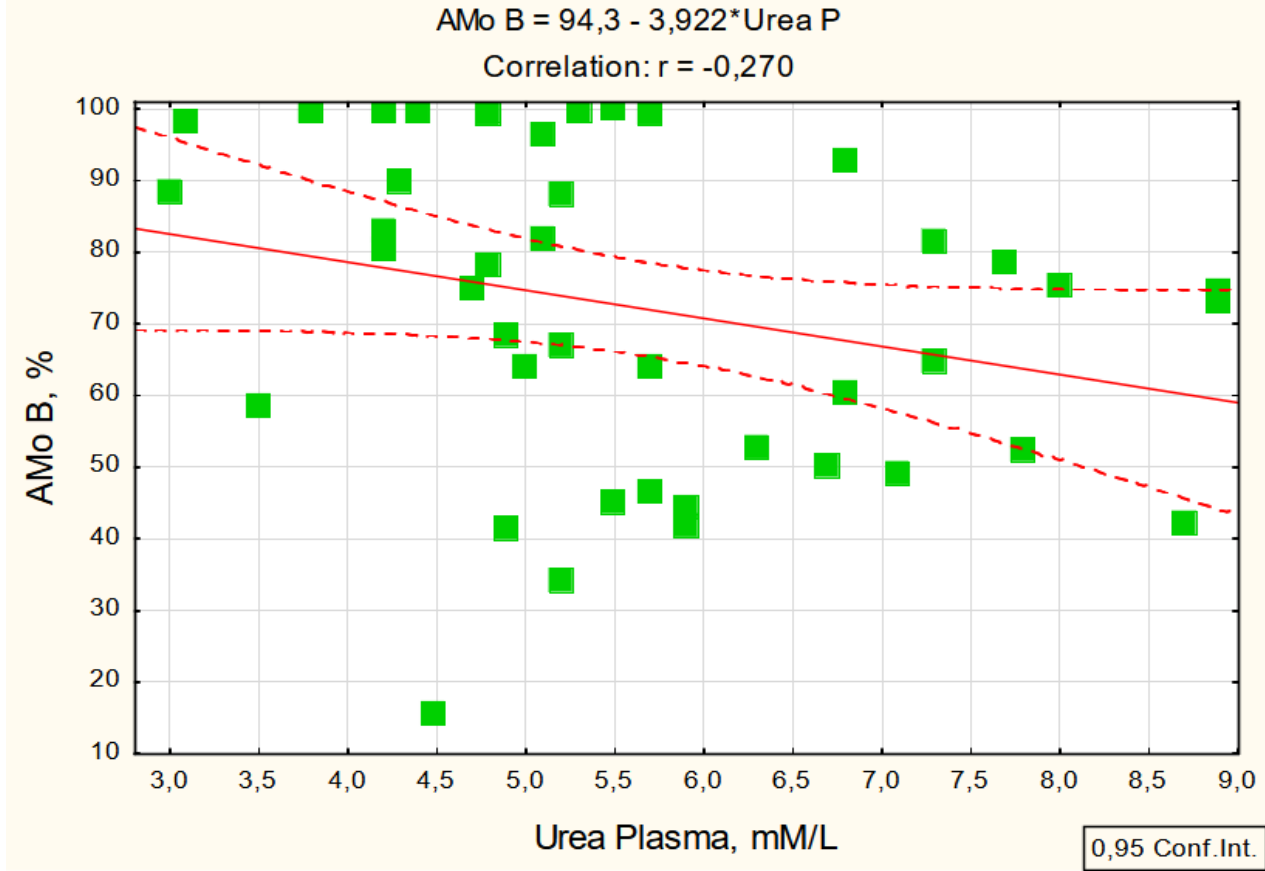

Fig. 5. Scatterplot of correlation between Urea Plasma (X-line) and AMo HRV basal (Yline) 


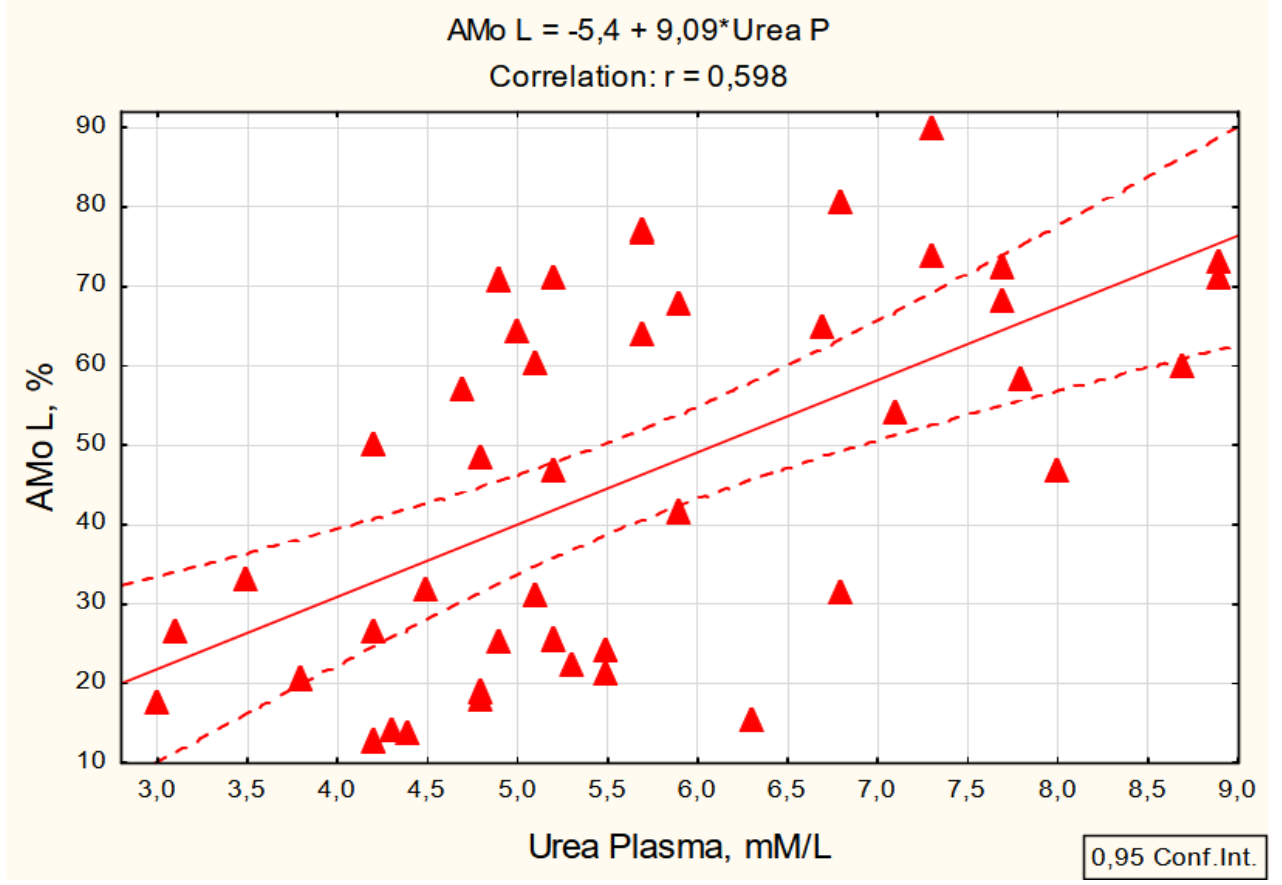

Fig. 6. Scatterplot of correlation between Urea Plasma (X-line) and AMo HRV after loading (Y-line)

Another parameter of regulatory systems is autonomic reactivity, the quantitative measure of which is the ratio of the stress index standing to such lying (SIS/SILd) [3]. Normal (sympathicotonic) reactivity is indicated by SIS/SILd in the range of $0,7 \div 1,5$ at SILd $>91$ units, $0,9 \div 1,8$ at SILd $90 \div 61$ units, $1,0 \div 2,5$ at SILd $60 \div 30$ units. For a more convenient logarithmic scale, the corresponding ranges are: $-0,36 \div 0,405 ;-0,10 \div 0,59 ; 0 \div 0,92$. As the sympathetic tone increases both at transition from a lying position to standing, and in response to physical activity, this scale, in our opinion, is quite acceptable and concerning the $\ln (\mathrm{SIL} / \mathrm{SIB})$ ratio applied by us. Accepting this, we state normal autonomic reactivity only in $16 \%$ of cases, while in $64 \%$ of cases there was asympathicotonic reactivity, and in $20 \%$ hypersympathicotonic (Fig. 7). The same figure illustrates the positive correlation between autonomic reactivity and plasma urea levels.

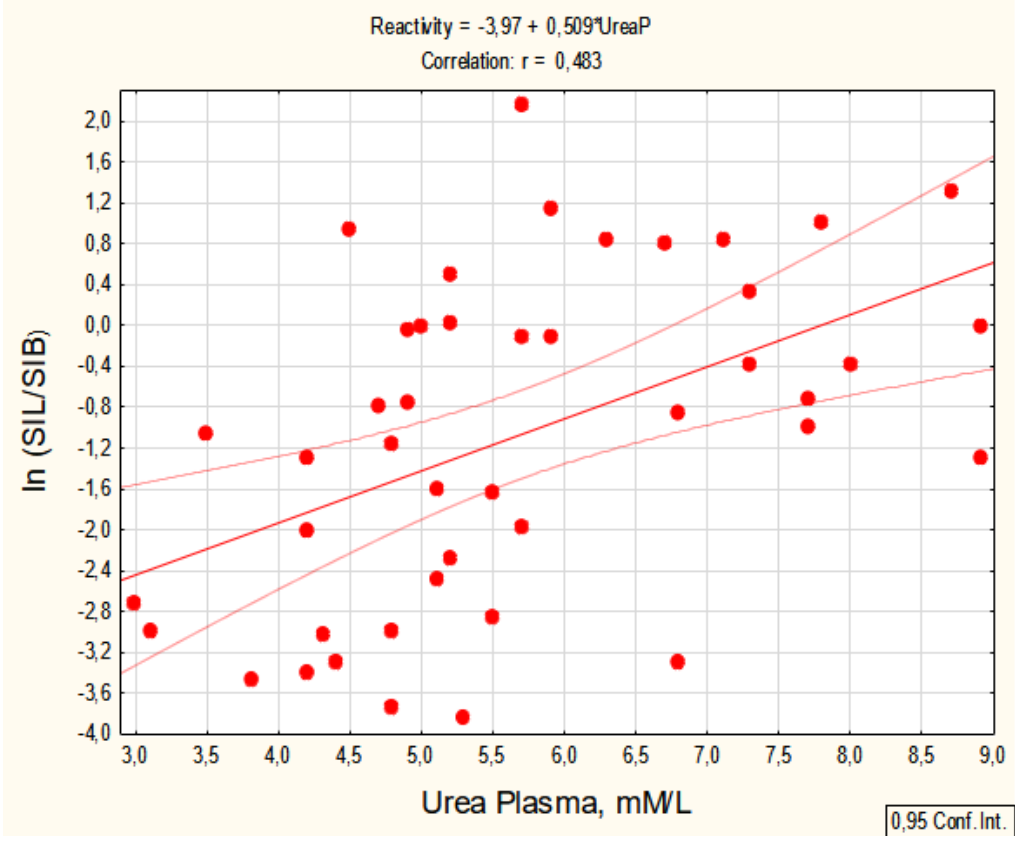

Fig. 7. Scatterplot of correlation between Urea P (X-line) and ANS Reactivity (Y-line) 
In the next step of the analysis, a regression model was constructed for each plasma and urine nitrogenous metabolite by stepwise exclusion until the maximum level of adjusted $\mathrm{R}^{2}$ was reached. As a result, it turned out that some regression models included parameters with an insignificant correlation coefficient, while some parameters with a significant correlation were outside the model.

From the regression model it follows that Urea plasma downregulates basal sympathetic tone and exercise-induced vagal tone, while upregulates the autonomic reactivity and level of circulating catecholamines. Judging by adjusted $\mathrm{R}^{2}$, the rate of autonomic modulation is $44 \%$ (Table 2 and Fig. 8).

Table 2. Regression Summary for Urea Plasma

$\mathrm{R}=0,700 ; \mathrm{R}^{2}=0,489 ;$ Adjusted $\mathrm{R}^{2}=0,437 ; \mathrm{F}_{(4,4)}=9,3 ; \mathrm{p}<10^{-4}$

\begin{tabular}{|l|l|l|l|l|l|l|l|}
\hline & & Beta & $\begin{array}{l}\text { St. Err. } \\
\text { of Beta }\end{array}$ & B & $\begin{array}{l}\text { SE } \\
\text { of B }\end{array}$ & $\mathrm{t}_{(39)}$ & $\begin{array}{l}\text { p- } \\
\text { level }\end{array}$ \\
\hline Variables & $\mathrm{r}$ & & Intercpt & 12,96 & 3,18 & 4,08 & 0,0002 \\
\hline MxDMn HRV after loading, sec & $-0,65$ & $-0,959$ & 0,378 & $-12,328$ & 4,866 & $-2,53$ & 0,015 \\
\hline Mode HRV after loading, sec & $-0,66$ & $-0,327$ & 0,231 & $-4,885$ & 3,452 & $-1,42$ & 0,165 \\
\hline AMo HRV basal, \% & $-0,27$ & $-0,379$ & 0,321 & $-0,026$ & 0,022 & $-1,18$ & 0,244 \\
\hline $\ln$ (SIL/SIB) as ANS Reactivity & 0,48 & $-0,915$ & 0,541 & $-0,867$ & 0,513 & $-1,69$ & 0,099 \\
\hline
\end{tabular}

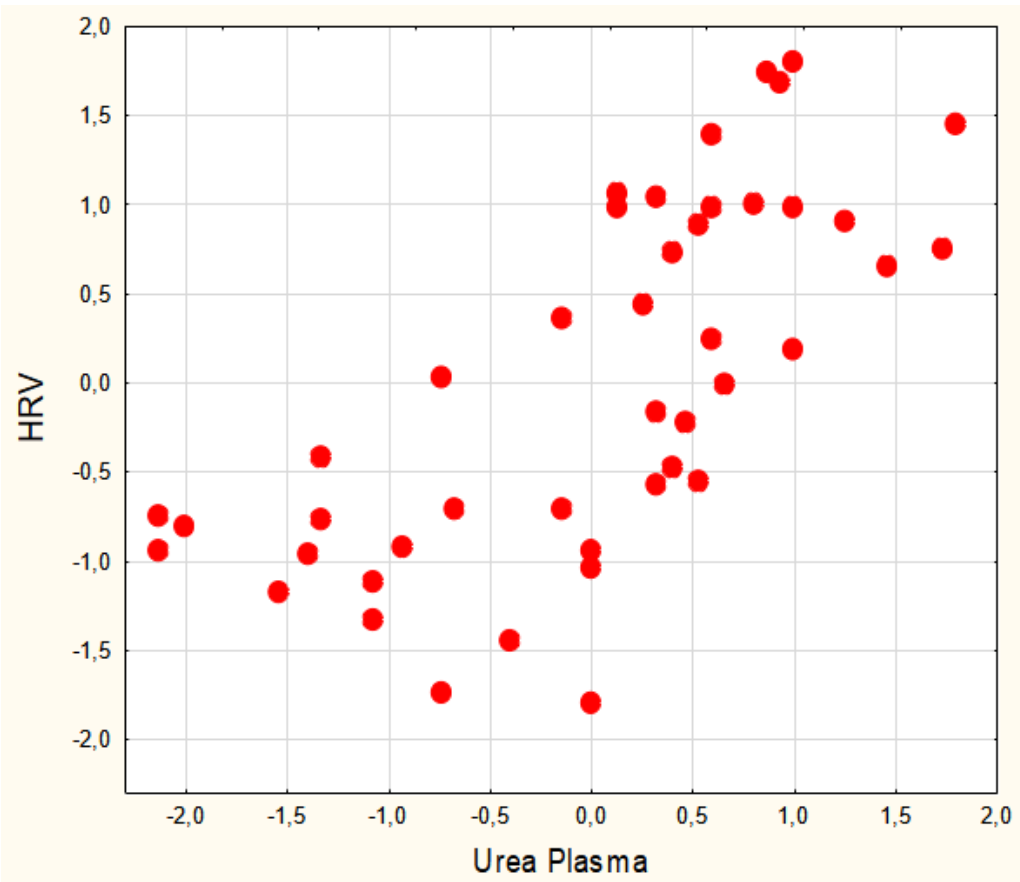

$\mathrm{R}=0,700 ; \mathrm{R}^{2}=0,489 ; \chi^{2}{ }_{(4)}=26,9 ; \mathrm{p}<10^{-4} ; \Lambda$ Prime $=0,511$

Fig. 8. Scatterplot of canonical correlation between Urea Plasma level (X-line) and parameters of HRV (Y-line)

Urea urine also downregulates basal sympathetic tone and upregulates the autonomic reactivity while upregulates the vagal tone. Judging by adjusted $\mathrm{R}^{2}$, the rate of autonomic modulation is $28 \%$ (Table 3 and Fig. 9).

Creatinine plasma upregulates both exercise-induced vagal tone and the autonomic reactivity. Judging by adjusted $\mathrm{R}^{2}$, the rate of autonomic modulation is $21 \%$ (Table 4 and Fig. $10)$.

Uric acid urine upregulates the autonomic reactivity and basal vagal tone while downregulates its exercise-induced change as well as basal Stress index. Judging by adjusted $\mathrm{R}^{2}$, the rate of autonomic modulation is $39 \%$ (Table 5 and Fig. 11). 
Table 3. Regression Summary for Urea Urine

$\mathrm{R}=0,531 ; \mathrm{R}^{2}=0,282 ;$ Adjusted $\mathrm{R}^{2}=0,228 ; \mathrm{F}_{(3,4)}=5,2 ; \mathrm{p}=0,004$

\begin{tabular}{|l|l|l|c|c|c|c|c|}
\hline & & Beta & $\begin{array}{l}\text { St. Err. } \\
\text { of Beta }\end{array}$ & B & $\begin{array}{l}\text { SE } \\
\text { of B }\end{array}$ & $\mathrm{t}_{(39)}$ & $\begin{array}{l}\text { p- } \\
\text { level }\end{array}$ \\
\hline Variables & $\mathrm{r}$ & & Intercpt & 265,3 & 141,7 & 1,87 & 0,068 \\
\hline MxDMn HRV basal, sec & 0,51 & 0,639 & 0,216 & 1395 & 472 & 2,96 & 0,005 \\
\hline $\ln$ (SIL/SIB) as ANS Reactivity & 0,29 & 0,248 & 0,273 & 16,34 & 17,99 & 0,91 & 0,369 \\
\hline AMo HRV basal, \% & $-0,35$ & 0,335 & 0,354 & 1,604 & 1,692 & 0,95 & 0,349 \\
\hline
\end{tabular}

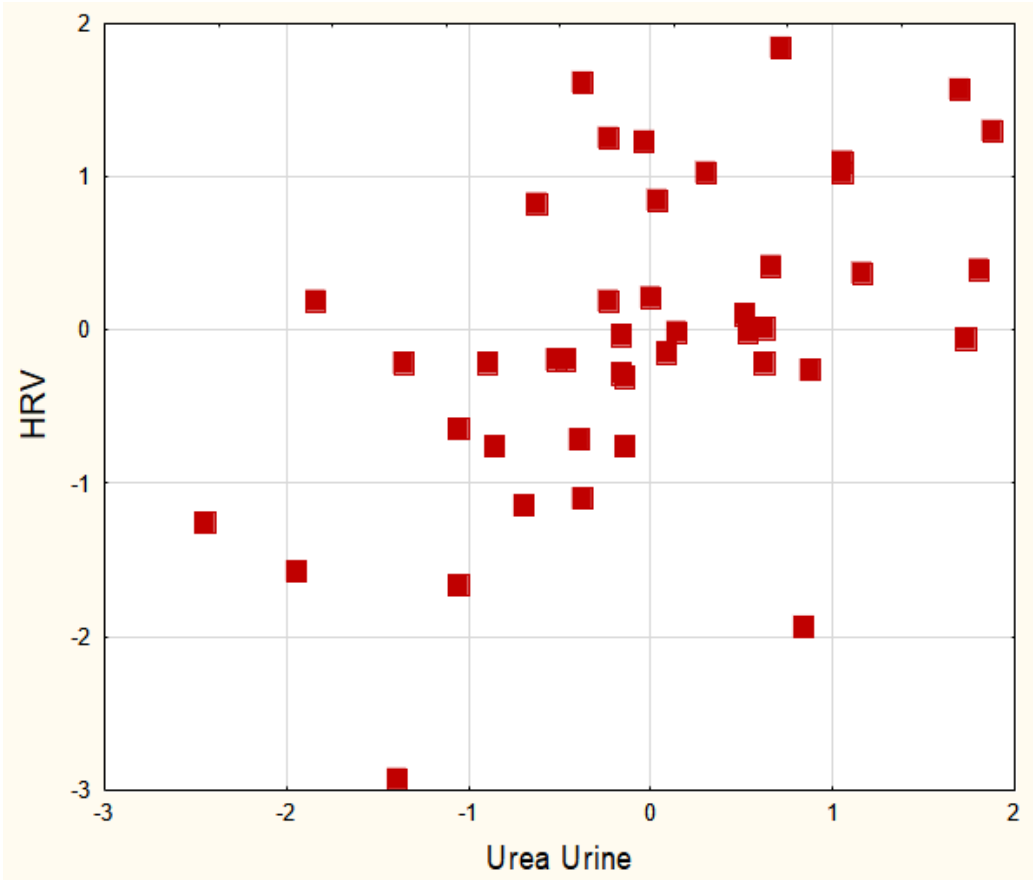

$\mathrm{R}=0,531 ; \mathrm{R}^{2}=0,282 ; \chi_{(3)}^{2}=13,4 ; \mathrm{p}=0,004 ; \Lambda$ Prime $=0,718$

Fig. 9. Scatterplot of canonical correlation between Urea Urine level (X-line) and parameters of HRV (Y-line)

Table 4. Regression Summary for Creatinine Plasma

$\mathrm{R}=0,457 ; \mathrm{R}^{2}=0,209 ;$ Adjusted $\mathrm{R}^{2}=0,170 ; \mathrm{F}_{(2,4)}=5,4 ; \mathrm{p}=0,008$

\begin{tabular}{|l|l|l|c|l|l|l|c|}
\hline & & Beta & $\begin{array}{l}\text { St. Err. } \\
\text { of Beta }\end{array}$ & B & $\begin{array}{l}\text { SE } \\
\text { of B }\end{array}$ & t $_{(39)}$ & $\begin{array}{l}\text { p- } \\
\text { level }\end{array}$ \\
\hline Variables & $\mathrm{r}$ & & Intercpt & 96,5 & 4,36 & 22 & $10^{-6}$ \\
\hline MxDMn HRV after loading, sec & 0,43 & $-0,711$ & 0,292 & $-73,2$ & 30,1 & $-2,43$ & 0,019 \\
\hline $\ln$ (SIL/SIB) as ANS Reactivity & 0,31 & $-0,318$ & 0,292 & $-2,41$ & 2,22 & $-1,09$ & 0,284 \\
\hline
\end{tabular}




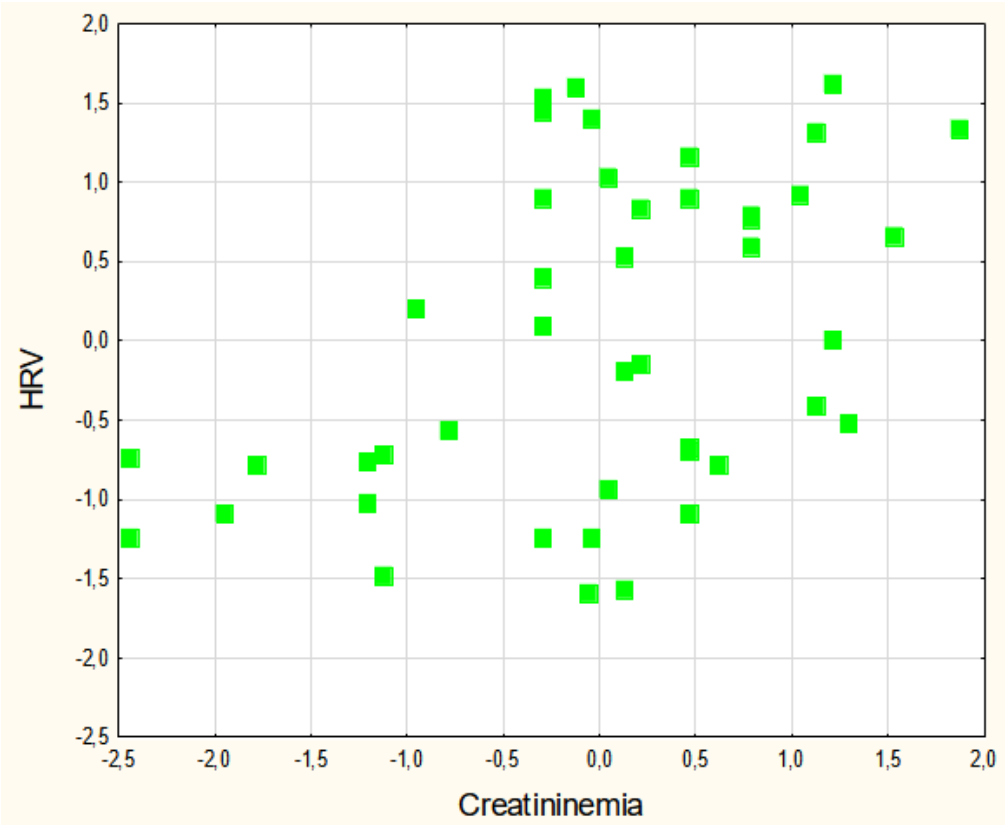

$\mathbf{R}=0,457 ; \mathbf{R}^{2}=0,209 ; \chi_{(2)}^{2}=9,6 ; \mathbf{p}=0,008 ; \Lambda$ Prime $=0,791$

Fig. 10. Scatterplot of canonical correlation between Creatinine Plasma level (X-line) and parameters of HRV (Y-line)

Table 5. Regression Summary for Uric acid Urine

$\mathrm{R}=0,623 ; \mathrm{R}^{2}=0,388 ;$ Adjusted $\mathrm{R}^{2}=0,326 ; \mathrm{F}_{(4,4)}=6,2 ; \mathrm{p}=0,0006$

\begin{tabular}{|l|l|l|l|l|l|l|l|}
\hline & & Beta & $\begin{array}{l}\text { St. Err. } \\
\text { of Beta }\end{array}$ & B & $\begin{array}{l}\text { SE } \\
\text { of B }\end{array}$ & $\mathrm{t}_{(39)}$ & $\begin{array}{l}\text { p- } \\
\text { level }\end{array}$ \\
\hline Variables & $\mathrm{r}$ & & Intercpt & $-10,5$ & 4,65 & $-2,22$ & 0,030 \\
\hline MxDMn HRV basal, sec & 0,51 & 2,204 & 0,633 & 36,61 & 10,51 & 3,48 & 0,001 \\
\hline $\ln$ (SIL/SIB) as ANS Reactivity & 0,25 & $-0,277$ & 0,246 & $-0,139$ & 0,123 & $-1,13$ & 0,266 \\
\hline $\ln$ SI basal, units & $-0,43$ & 1,823 & 0,650 & 1,704 & 0,607 & 2,81 & 0,008 \\
\hline (MxDMn) L/(MxDMn) B & $-0,33$ & $-0,403$ & 0,265 & $-0,120$ & 0,079 & $-1,52$ & 0,136 \\
\hline
\end{tabular}

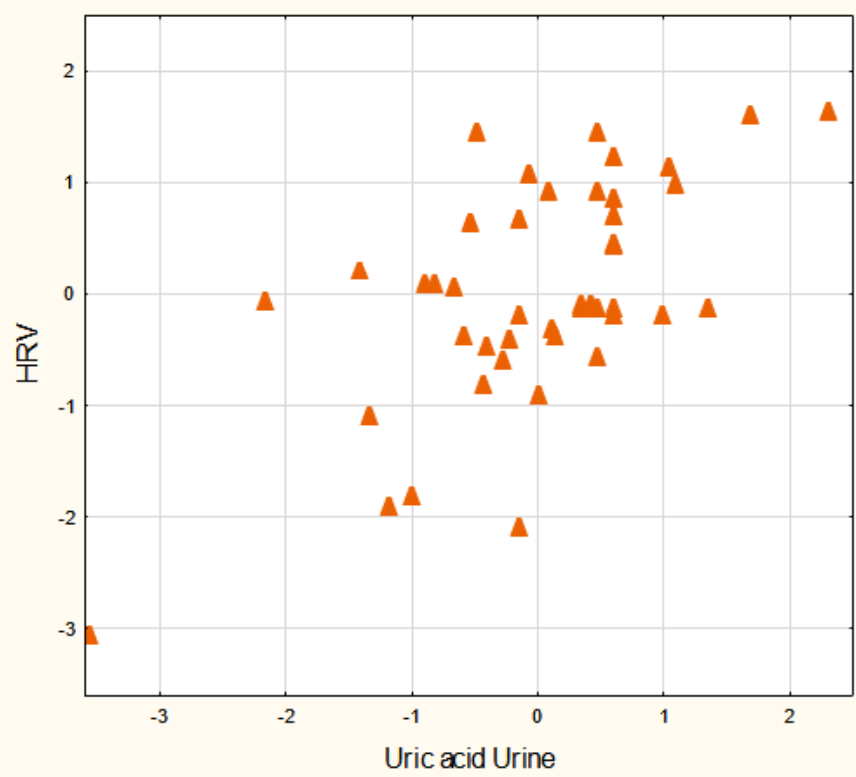

$\mathrm{R}=0,623 ; \mathrm{R}^{2}=0,388 ; \chi_{(4)}^{2}=19,7 ; p=0,0006 ; \Lambda$ Prime $=0,612$

Fig. 11. Scatterplot of canonical correlation between Uric acid Urine (X-line) and parameters of HRV (Y-line) 
No significant correlations were found for Creatinine urine, Uric acid plasma and Bilirubinemia.

At the final stage, following the accepted algorithm, the canonical correlation between the parameters of nitrogenous metabolism, on the one hand, and the parameters of ANS - on the other hand, is analyzed.

As a result of canonical analysis, two pairs of canonical roots were formed. Nitrogenous root of the first pair (Table 6), judging by the factor loads, represents mainly Urea and Creatinine plasma, and to a lesser extent Uric acid and Urea urine, but inversely. The ANS root of the first pair contains inversely information about mainly the vagal tone both exerciseinduced and basal as well as its change while direct information about exercise-induced level of circulating catecholamines and basal Stress index and its change after load. The vegetotropic effect of these nitrogenous metabolites, judging by the coefficient of determination, is $55,8 \%$ (Fig. 12).

Table 6. Factor load on first pair of canonical roots of nitrogenous metabolites and HRV parameters

\begin{tabular}{|l|l|}
\hline Left set & Root 1 \\
\hline Urea Plasma & $\mathbf{0 , 8 9 2}$ \\
\hline Creatininemia & $\mathbf{0 , 5 5 2}$ \\
\hline Uric acid Urine & $\mathbf{- 0 , 3 3 2}$ \\
\hline Urea Urine & $\mathbf{- 0 , 2 3 9}$ \\
\hline Right set & Root 1 \\
\hline MxDMn after loading & $-0,819$ \\
\hline MxDMn basal & $-0,390$ \\
\hline (MxDMn) L/(MxDMn) B & $-0,157$ \\
\hline AMo basal & $-0,208$ \\
\hline Mode after loading & $-0,784$ \\
\hline ANS Reactivity & 0,507 \\
\hline Stress Index basal & 0,393 \\
\hline
\end{tabular}

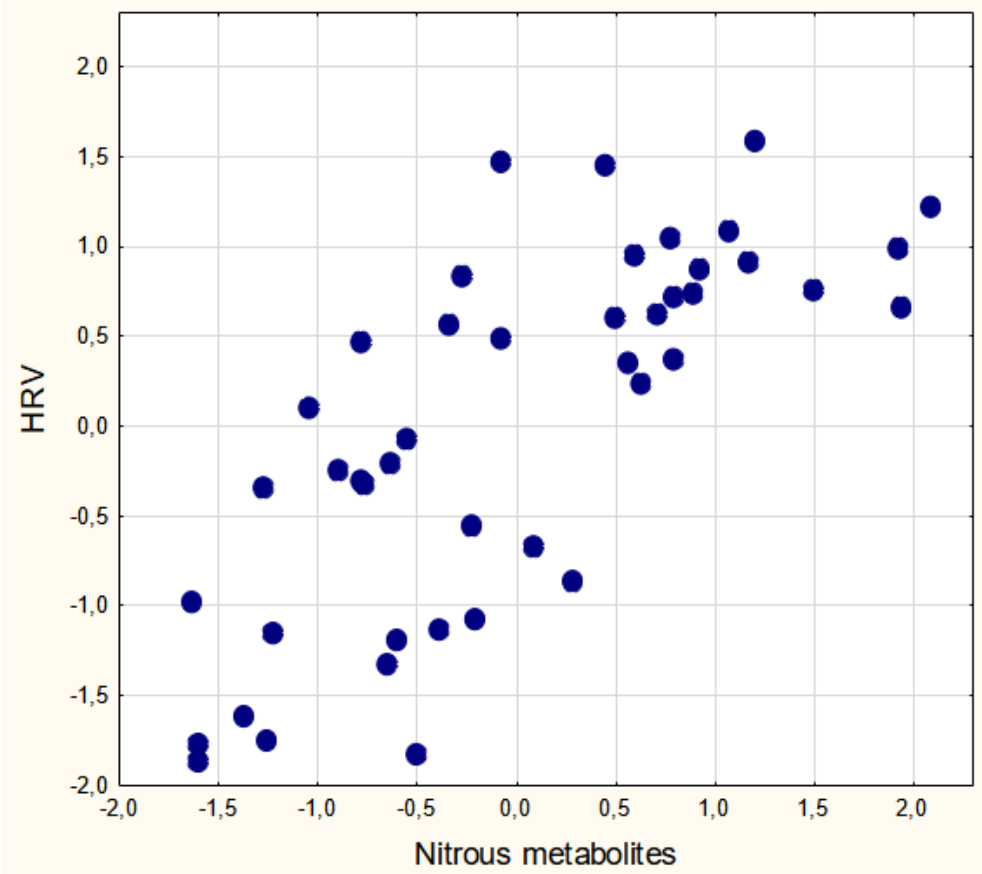

$\mathrm{R}=0,747 ; \mathrm{R}^{2}=0,558 ; \chi_{(28)}^{2}=63 ; p=0,0002 ; \Lambda$ Prime $=0,184$

Fig. 12. Scatterplot of canonical correlation between nitrogenous metabolites (X-line) and parameters of HRV (Y-line). First pair of canonical roots 
The nitrogenous root of the second pair (Table 7) represents mainly Uric acid and Urea urine, and to a lesser extent Urea and Creatinine plasma. Note the same sign of the factor loads. This constellation of nitrogenous metabolites primarily downregulates basal sympathetic tone and stress index, as well as exercise-induced vagal tone and its change while upregulates the basal vagal tone, ANS reactivity and level of circulating catecholamines. The vegetotropic effect of these nitrogenous metabolites is $45,6 \%$ (Fig. 13).

Table 7. Factor load on second pair of canonical roots of nitrogenous metabolites and HRV parameters

\begin{tabular}{|l|c|}
\hline Left set & Root 2 \\
\hline Uric acid Urine & $\mathbf{- 0 , 8 5 3}$ \\
\hline Urea Urine & $\mathbf{- 0 , 6 9 1}$ \\
\hline Urea Plasma & $\mathbf{- 0 , 2 7 2}$ \\
\hline Creatininemia & $-0,138$ \\
\hline Right set & Root 2 \\
\hline AMo basal & 0,708 \\
\hline (MxDMn) L/MxDMn) B & 0,689 \\
\hline Stress Index basal & 0,684 \\
\hline MxDMn after loading & 0,430 \\
\hline MxDMn basal & $-0,787$ \\
\hline ANS Reactivity & $-0,711$ \\
\hline Mode after loading & 0,501 \\
\hline
\end{tabular}

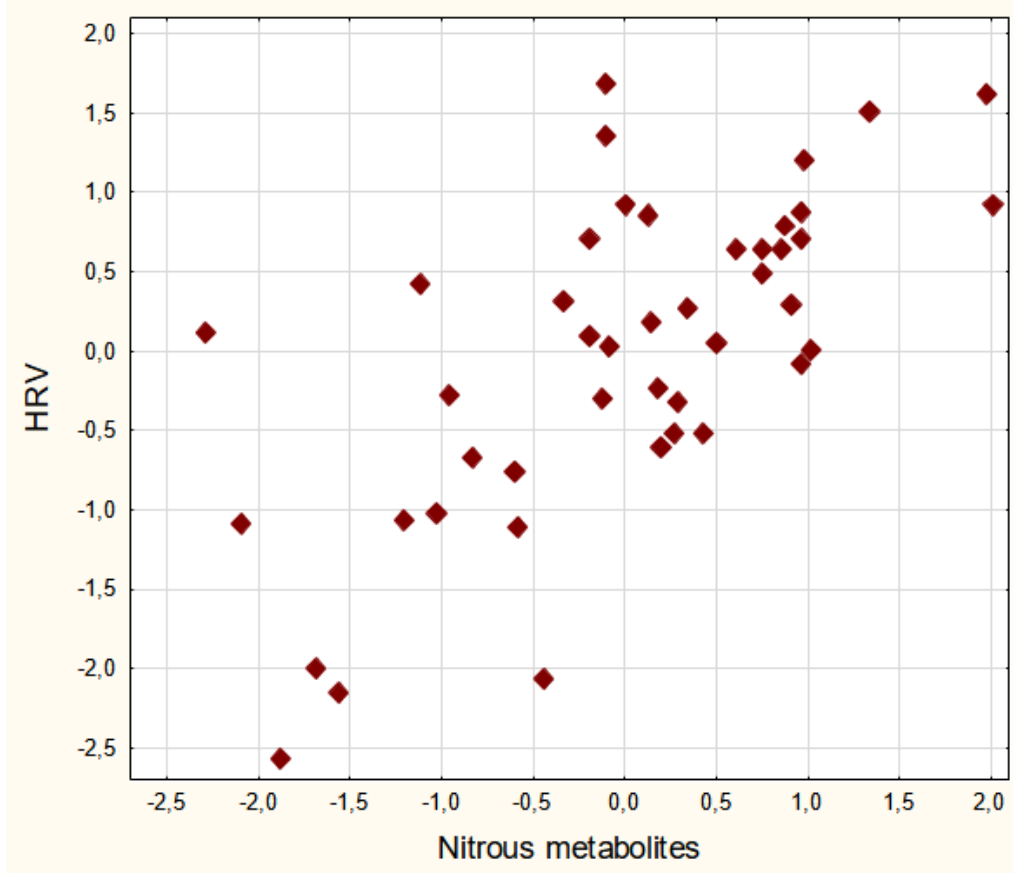

$\mathrm{R}=0,676 ; \mathrm{R}^{2}=0,456 ; \chi_{(18)}^{2}=32 ; \mathrm{p}=0,020 ; \Lambda$ Prime $=0,416$

Fig. 13. Scatterplot of canonical correlation between nitrogenous metabolites (X-line) and parameters of HRV (Y-line). Second pair of canonical roots

Our data on the vegetotropic activity of Uric acid are ambiguous. Thus, no significant relationships were found between HRV parameters and uricemia, instead, vagotonic activity of uricosuria was noted. Interestingly, the data of other authors are also ambiguous. In particular, Shehab AM et al [32] in patients with chronic heart failure also found no significant linear correlation between allopurinol-induced changes in serum Uric acid concentrations and changes in parameters of HRV (SDNN and RMSSD as markers of vagal 
tone) and mean heart rate. While Kunikullaya KU et al [20] found that serum Uric acid levels were high in prehypertensives and hypertensives as compared to normal subjects; further, there was statistically significant correlation seen between Uric acid levels and sympathetic domain parameters particularly among prehypertensives. Passos RS et al [25] showed that the hyperuricemic older adults exhibited significant higher values for $\mathrm{V} 0 \%$ and lower values for V2\% parameters when compared to normouricemic older adults. These results suggesting a sympathovagal imbalance in hyperuricemic older adults, characterized by greater sympathetic predominance $(0 \mathrm{~V} \%)$ and lower vagal modulation $(2 \mathrm{~V} \%)$ at rest conditions.

Instead, we found a significant positive correlation between plasma urea and creatinine with sympathetic tone, but only after exercise, whereas in basal conditions the correlation was weakly negative. Another ambiguity is manifested in a significant positive correlation of urinary urea, but not urinary creatinine with basal vagal tone. Unfortunately, there is no one to compare our data with, as we could not find analogues on PubMed/PMC resources.

Despite all these contradictions, given the well-documented autonomic-immune relationships [24,34], our data provide good reason to believe that the immunotropic activity of urea and creatinine, as well as uric acid is realized through the autonomic nervous system through adreno- and cholinoreceptors of immunocytes.

The analysis of 10 most important basic life support systems of human body cardiovascular (CVS), respiratory (RS), nervous (NS), digestive (DS), endocrine (ES), immune (IS), excretory (EXS), brain (BS), musculo-skeletal (MSS), hematopoietic (HS) was carried out. Based on this analysis two levels of ensuring the reliability of organism's work were revealed: sequential and parallel.The system of logical equations for reduced sequential system is: Ys1 = CVS RS BS, where is the notation for the conjunctions of set elements. The system of logical equations for the reduced parallel system is: Ys2 = NS DS ES IS HS EXS MSS, where is the disjunction of the scheme elements. Visualization of human STC changes the concept of the kinetics of age-related changes in the organism and the role of determinants of health as a stable factor accompanying a uniform, smooth transition from the most pronounced functions of the body to their gradual extinction. For human STC is formulated the following regularity kinetics of involutionary processes: after 30 years of age in the human body morphological changes regress in arithmetic progression, and the functions of organs in a geometric one. Assumption of health as a state redundancy of functions is suggested [36].

The research is devoted to the fundamental issue of medicine and biology - the study of factors limiting the life span of a person. As a model, the system of adaptation of the human body to the forces of natural gravity is chosen, the disadaptation to which manifests itself in falls and everyday injuries. The object of the study was the selection of severe fractures of bone tissue due to fall, taken in the age aspect. Statistical and meta-analytical research methods were used. It is shown that the age-related increase in mortality due to household falls, coming to severe bone fractures, is non-linear and increases in geometric progression. As a result of the coincidence of the age characteristics of bone fragility and age-related kidney function, an assumption is made about the role of involution of the renal tissue in the development of osteoporosis in the elderly and the need for a new approach to the prevention of osteoporosis and domestic injuries [37].

\section{ACKNOWLEDGMENT}

We express sincere gratitude to administration of sanatorium "Perlyna Prykarpattya" of Ministry of Internal Affairs of Ukraine for help in conducting this investigation. 


\section{ACCORDANCE TO ETHICS STANDARDS}

Tests in patients are conducted in accordance with positions of Helsinki Declaration 1975 and directive of National Committee on ethics of scientific researches. During realization of tests from all participants the informed consent is got and used all measures for providing of anonymity of participants.

Conflict of Interest. The authors declare that there is no conflict of interest that could be perceived as interfering with publication of the article.

Competing Interests. The authors declare that they have no competing interests.

Informed Consent. Informed consent was obtained from all individual participants included in the study. All subjects of the institutional survey gave consent for anonymized data to be used for publication purposes.

Funding sources. This study has not received any financial support from any government, community or commercial organization.

\section{REFERENCES}

1. Apasov S, Chen JF, Smith P, Sitkovsky M. $A_{2 A}$ receptor dependent and $A_{2 A}$ receptor independent effects of extracellular adenosine on murine thymocytes in condicion of adenosine deaminase deficiency. Blood. 2000; 95(12): 3859-3867.

2. Avilla MN, Malecki KMC, Hahn ME, Wilson RH, Bradfield CA. The Ah Receptor: Adaptive Metabolism, Ligand Diversity, and the Xenokine Model. Chem Res Toxicol. 2020; 33(4): 860-879.

3. Baevskiy RM, Ivanov GG. Heart Rate Variability: theoretical aspects and possibilities of clinical application [in Russian]. Ultrazvukovaya i funktsionalnaya diagnostika. 2001; 3: 106127.

4. Baevskiy RM, Kirillov OI, Kletskin SZ. Mathematical Analysis of Changes in Heart Rate by Stress [in Russian]. Moskva. Nauka; 1984: 221 p.

5. Belotserkovskiy ZB. Determination of physical fitness. In: Instrumental Methods of Research of Cardiovascular System. Edited by Vinogradova TS. [in Russian]. Moskva. Meditsina; 1986: 394-405.

6. Esser C, Rannug A. The aryl hydrocarbon receptor in barrier organ physiology, immunology, and toxicology. Pharmacol Rev. 2015; 67(2): 259-279.

7. Ghaemi-Oskouie F, Shi Yan. The role of uric acid as an endogenous danger signal in immunity and inflammation. Curr Rheumatol Rep. 2011; 13(2): 160-166.

8. Goryachkovskiy AM. Clinical Biochemistry [in Russian]. Odesa: Astroprint; 1998: 608

p.

9. Gozhenko AI. Functional-metabolic continuum [in Russian]. J of NAMS of Ukraine. 2016; 22 (1): 3-8.

10. Gozhenko AI, Smagliy VS, Korda IV, Badiuk NS, Zukow W, Popovych IL. Functional relationships between parameters of uric acid exchange and immunity in female rats. Actual problems of transport medicine. 2019; 4(58): 123-131.

11. Gozhenko AI, Smagliy VS, Korda IV, Badiuk NS, Zukow W, Popovych IL. Features of immune status in different states of uric acid metabolism in female rats. Journal of Education, Health and Sport. 2019; 9(12): 167-180.

12. Gozhenko AI, Smagliy VS, Korda IV, Badiuk NS, Zukow W, Kovbasnyuk MM, Popovych IL. Relationships between parameters of uric acid exchange and immunity as well as microbiota in patients with neuroendocrine-immune complex dysfunction. Journal of Education, Health and Sport. 2020; 10(1): 165-175. 
13. Gozhenko AI, Smagliy VS, Korda IV, Badiuk NS, Zukow W, Kovbasnyuk MM, Popovych IL. Relationships between changes in uric acid parameters metabolism and parameters of immunity and microbiota in patients with neuroendocrine-immune complex dysfunction. Journal of Education, Health and Sport. 2020; 10(2): 212-222.

14. Gozhenko AI, Zukow W, Polovynko IS, Zajats LM, Yanchij RI, Portnichenko VI, Popovych IL. Individual Immune Responses to Chronic Stress and their Neuro-Endocrine Accompaniment. RSW. UMK. Radom. Torun; 2019: 200 p.

15. Hoskin DW, Mader JS, Furlong SJ, Conrad DM, Blay J. Inhibition of T cell and NK cell function by adenosine and its contribution to immune evasion by tumor cells (Review). Int J Oncol. 2008; 32(3): 527-535.

16. Huang S, Apasov S, Koshiba M, Sitkovski M. Role of $A_{2 A}$ extracellular adenosine receptor mediated signaling in adenosine mediated inhibition of of $\mathrm{T}$-cell activation and expansion. Blood. 1997; 90(4): 1600-1610.

17. Ivassivka SV, Popovych IL, Aksentiychuk BI, Flyunt IS. Physiological Activity of Uric Acid and its Role in the Mechanism of Action of Naftussya Water [in Ukrainian]. Kyiv. Computerpress; 2004: 163 p.

18. Kostyuk PG, Popovych IL, Ivassivka SV (editors). Chornobyl', Adaptive and Defensive Systems, Rehabilitation [in Ukrainian]. Kyiv. Computerpress; 2006: 348 p.

19. Kuchma IL, Gozhenko AI, Bilas VR, Ruzhylo SV, Kovalchuk GY, Nahurna YV, Zukow $\mathrm{W}$, Popovych IL. Immunotropic effects of nitrogenous metabolites (creatinine, urea, uric acid and bilirubin) in humans exposed to the factors of the accident at the Chornobyl nuclear power plant. Journal of Education, Health and Sport. 2020; 10(12): 314-331.

20. Kunikullaya KU, Purushottam N, Prakash V, Mohan S, Chinnaswamy R. Correlation of serum uric acid with heart rate variability in hypertension. Hipertens Riesgo Vasc. 2015; 32(4): 133-141.

21. Loboda MV, Babov KD, Steblyuk VV (editors). Diseases of Maladaptation in the Practice of Rehabilitation Medicine [in Ukrainian]. Kyiv. NAU; 2004: 200 p.

22. Martínez-Reyes CP, Manjarrez-Reyna AN, Méndez-García LA, et al. Uric Acid Has Direct Proinflammatory Effects on Human Macrophages by Increasing Proinflammatory Mediators and Bacterial Phagocytosis Probably via URAT1. Biomolecules. 2020; 10(4): 576.

23. Morelli M, Carta AR, Kachroo A, Schwarzschild A. Pathophysiological roles for purines: adenosine, caffeine and urate. Prog Brain Res. 2010; 183: 183-208.

24. Nance DM, Sanders VM. Autonomic innervation and regulation of immune system (1987-2007). Brain Behav Immun. 2007; 21(6): 736-745.

25. Passos RS, Ribeiro ÍJS, Freire IV, et al. Hyperuricemia is associated with sympathovagal imbalance in older adults. Arch Gerontol Geriatr. 2020; 90:104132.

26. Phelan D, Winter GM, Rogers WJ, Lam JC, Denison MS. Activation of the Ah receptor signal transduction pathway by bilirubin and biliverdin. Arch Biochem Biophys. 1998; 357(1): 155-163.

27. Popovych IL, Gozhenko AI, Zukow W, Polovynko IS. Variety of Immune Responses to Chronic Stress and their Neuro-Endocrine Accompaniment. Scholars' Press. Riga; 2020: 172 p.

28. Popovych IL, Flyunt IS, Alyeksyeyev OI, Barylyak LG, Bilas VR. Sanogenetic Bases of Rehabilitation on Spa Truskavets' Urological Patients from Chornobylian Contingent [in Ukrainian]. Kyiv. Computerpress; 2003: 192 p.

29. Popovych IL, Gozhenko AI, Kuchma IL, Zukow W, Bilas VR, Kovalchuk GY, Ivasivka AS. Immunotropic effects of so-called slag metabolites (creatinine, urea, uric acid and bilirubin) at rats. Journal of Education, Health and Sport. 2020; 10(11): 320-336.

30. Quintana FJ, Sherr DH. Aryl hydrocarbon receptor control of adaptive immunity.

Pharmacol Rev. 2013; 65(4): 1148-1161. 
31. Romodanov AP (editor). Postradiation Encephalopathy. Experimental Researches and Clinical Observations [in Ukrainian and Russian]. Kyiv. USRI of Neurosurgery; 1993: 224 p. 32. Shehab AM, Butler R, MacFadyen RJ, Struthers AD. A placebo-controlled study examining the effect of allopurinol on heart rate variability and dysrhythmia counts in chronic heart failure. Br J Clin Pharmacol. 2001; 51(4): 329-334.

33. Smagliy VS, Gozhenko AI, Korda IV, Badiuk NS, Zukow W, Kovbasnyuk MM, Popovych IL. Variants of uric acid metabolism and their immune and microbiota accompaniments in patients with neuroendocrine-immune complex dysfunction. Actual problems of transport medicine. 2020; 1(59): 114-125.

34. Thayer JF, Sternberg EM. Neural aspects of immunomodulation: Focus on the vagus nerve. Brain Behav Immun. 2010; 24(8): 1223-1228.

35. Vigano S, Alatzoglou D, Irving M, Menetrier-Caux Ch, Caux Ch, Romero P, Coukos G. Targeting adenosine in cancer immunotherapy to enhance T-cell function. Front Immunol. 2019; 10: 925.

36. Gozhenko A., Biryukov V., Gozhenko O., Zukow, W. Health as a space-time continuum. Journal of Education, Health and Sport, 2018; 8(11): 763-777. DOI: http://dx.doi.org/10.5281/zenodo.2657000.

37. Gozhenko A., Biryukov V., Muszkieta R., Zukow, W. Physiological basis of human longevity: the concept of a cascade of human aging mechanism. Collegium antropologicum, 2018; 42(2): 139-146. 